\title{
The Development Viewboard As an Information Media at Official Site Asosiation
}

\author{
Ninda Lutfiani ${ }^{1}$, Untung Rahardja ${ }^{2}$, Kartika Trissanti Khasanah ${ }^{3}$ \\ 1,2,3Universitas Raharja Jl. Jenderal Sudirman No.40, Cikokol, \\ Kec.Tangerang, Kota Tangerang, Banten 15117 \\ e-mail:ninda@raharja.info ${ }^{1}$, untung@raharia.info ${ }^{2}$, kartika.trissanti@raharia.info ${ }^{3}$
}

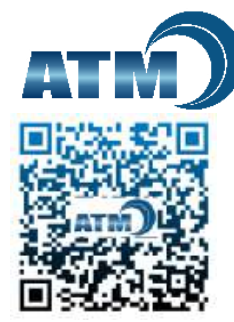

\section{To cite this document :}

Lutfiani, N., Rahardja, U., \& Khasanah, K.T. (2022). The Development Viewboard As an Information Media at Official Site Asosiation. Aptisi Transactions on Management (ATM), $6(1), 10-18$.

DOI :

https://doi.org/10.33050/atm.v6i1.1529

\begin{abstract}
Along the progress of the era and technological developments, making the human lifestyle cannot be separated from its use. In digital era nowadays, technology is used to make human needs easily. A website is important for the progress of an Association. One of the ways that the Association's Website can grow is by maintaining the Website. The APTISI website is designed using the WordPress CMS (Content Management System). WordPress is an open system software and designed by the PHP programming language and MYSQL database. This study is aim to develop a website by increasing the credibility of the association. In order to improve the statistics on website visits, it is necessary to have innovation and creativity in viewing and posting news on the website. The APTISI website make use of probability calculations and statistical data using a monitoring tool called statcounter. This tool functions to count the number of visitors based on unique visits which can be seen in the statistics column. In addition, the use of this statcounter is useful as a standard reference for website admins to update the viewboard on a better website in the future.standard for website admins to update the appearance of a better website in the future.
\end{abstract}

Keywords: Website, CMS, Wordpress, Data Statistic, Viewboard

\section{INTRODUCTION}

Currently, the world has experienced rapid advances in technology to facilitate human life. In every aspect of life, communication has a very important role. Such as in the fields of education, economy, entertainment and other fields [1]. Information technology is developing in line with the needs of an organization in facing a very tight world competition [2]. At present, information technology is a number of supporting factors that provide many benefits to society, especially the convenience produced by a technology [3]. Currently, social media is an important thing for the younger generation in their social life. Of course, this can also be used as a promotion [4].

In human life, technological developments have an important role for life [5]. The internet has a great influence on business and economic development, and various activities that previously could only be done directly can now be easily done anywhere and anytime using the internet [6]. Function testing helps explains how the design of a web can hinder users from achieving the main goal, so that identification is carried out where and how improvements need to be made [7] 


\subsection{Website Meaning}

Website is a global information media that can be accessed by the internet, so it has a wider reach than conventional information media such as magazines, newspapers, television or radio which are local in nature [8]. Arief said (2011) a website is an application that contains multimedia documents (images, animation, text, and video) that have the HTTP (Hypertext Transfer Protocol) protocol and can be accessed using software called a browser [9].

A website is a place on the internet located on a computer, which has a domain address called a URL (Uniform Resource Locator) [10]. The association website makes use of the internet to make it easier for Association members to share information openly with the public. This also has benefits for the organization in delivering information. Of course, the association website provides information about the association [11]. The most important part of an association website is an article or news. Sometimes students often underestimate the delivery of information in the form of news, because most of them do not really want to know about non-academic association issues [12].

\section{$1.2 \quad$ Association Meaning}

In the world of education, an association is very important to support the level of success of an educational institution, one of which is a private university [13][14]. An example of an association that is engaged in education and higher education is APTISI [15]. The Association of Indonesian Private Higher Education or can be known as APTISI is an internal organization whose members consist of all Private Universities (PTS) and all Private Higher Education Organizing Legal Entities (BHP-PTS) in Indonesia [16]. APTISI has a central location in Jakarta. The presence of an association website in an organization or company is one form of utilizing internet technology to provide effective and efficient information [17]. An alternative to solving this problem is by applying the official APTISI website to see the performance of the association's activities [18].

\subsection{Formulation of the Problems}

The need to conduct evaluations using certain methods or standards can reduce and determine the current condition of the website to the fullest [19]. Evaluation is part of a management system that has a plan. If you do not evaluate, an object will not be able to determine its quality [20][21]. Including in the design, implementation and results. Apart from evaluation, analysis on the system is also needed to find out what problems are contained therein. The analysis phase is a step or process of investigating a system that has the aim of finding answers related to how the system works, how to use the system, and time to use the system [22][23].

The problem that occurs is that since it was first created, the aptisi.or.id website is inconsistent in posting updates. This is due to the limited sources of information and availability of sources. However, usability has never been evaluated. Usability is a very important in a design consisting of efficiency, effectiveness, flexibility, safety, utility, ease of learning, and easy to remember [24][25].

Evaluation is carried out only based on criticism and suggestions from several users and the team that manages the website. The results of these criticisms and suggestions will then be accommodated and studied and discussed for improvements to the website. This is done for the overall evaluation of an informative and efficient website appearance for all readers [26].

There are 2 main things that are the advantages and disadvantages of the website. A website must have two aspects, namely aesthetics and usability [27]. Aesthetics has a focus on all artistic value and visual appeal on the website, one of which is the layout design element. While usability focuses on function, effectiveness of information presentation and efficiency [28].

Based on the description above, the problems that occur in this study are: (1) What is the most important thing in a website? (2) Why is the function and usability very important to support the function of a website?

\section{Research Method}

In this study, measuring the activeness of the APTISI website using a monitoring tool. To see an increase in the number of visits to the website in the future based on statistics from previous studies. The research method is a step used in a study based on the objectives set at the beginning of the study [29]. This study uses 2 (two) methods. Among them are data collection methods and systems development methods 


\subsection{Data Collection Methods}

The direct observation method or the so-called observation method is a method of collecting data by observing behavior in certain circumstances and then systematically writing down the results of the observed events and assessing the observed events [30]. By collecting data, it has the objective of obtaining the information needed to support the research process.

In using the data collection method, observation is carried out directly by monitoring and managing the aptisi.or.id website regularly at Raharja University. Which is where there is the Chairperson of APTISI Region IV Banten and also other APTISI members [11]. The research was conducted by obtaining information about APTISI activities in Region IV Banten.

\section{$2.2 \quad$ SWOT Analysis}

The SWOT analysis method is an analysis method with an approach to the condition of the object in 4 (four) categories. Among them are Strength, Weakness, Opportunity and Threat which will attack the APTISI official site system so that this analysis can be included in the SWOT analysis.

SWOT analysis is an important planning strategy for comparing internal factors. Which consists of strengths and weaknesses as well as internal and external, namely opportunities and threats [31].

\begin{tabular}{|c|l|l|}
\hline \multirow{2}{*}{$\begin{array}{c}\text { External and Internal } \\
\text { Factors }\end{array}$} & $\begin{array}{l}\text { Strength } \\
\text { Opportunity to access news } \\
\text { freely. With informative, clear } \\
\text { and efficient news } \\
\text { presentation. }\end{array}$ & $\begin{array}{l}\text { 1. The potential for } \\
\text { plagiarism in news content } \\
\text { 2. Lack of human resources } \\
\text { to regularly manage the } \\
\text { website }\end{array}$ \\
\hline \multicolumn{1}{|c|}{ Opportunity } & \multicolumn{1}{|c|}{ Strength Opportunity } & \multicolumn{1}{c|}{ Weakness Opportunity } \\
\hline $\begin{array}{l}\text { There is enthusiasm in } \\
\text { society that has turned to } \\
\text { easy access to information }\end{array}$ & $\begin{array}{l}\text { APTISI official site } \\
\text { development to make it more } \\
\text { user friendly }\end{array}$ & $\begin{array}{l}\text { Looking for human resources } \\
\text { who can be consistent in } \\
\text { manaing the website so that } \\
\text { it can run and keep } \\
\text { developing from time to time }\end{array}$ \\
\hline $\begin{array}{l}\text { The potential for false } \\
\text { information circulating in the } \\
\text { wider community }\end{array}$ & $\begin{array}{l}\text { Stilization of the comment } \\
\text { feature on the APTISI official } \\
\text { site }\end{array}$ & $\begin{array}{l}\text { Ensuring that the news } \\
\text { delivered is genuine and can } \\
\text { be accounted for }\end{array}$ \\
\hline
\end{tabular}

Table 1. SWOT Analysis Methods APTISI Official Site

The table above, is explains that the SWOT analysis is an underlying factor for external and internal factors. It consists of Strength, Weakness, Opportunity, and Threat. From this it can be concluded that with the formulation of the Strength and Opportunity Strategy (SO) from the comparison between Strength and Opportunity. By developing on the website so that it has more user-friendly features. Weakness and opportunity (WO) strategy can work based on weakness (weakness) and opportunity (opportunity). Having human resources who are competent in writing articles or news so that the association's function can run properly. By remaining consistent so that the delivery of information to the association is maintained and can develop. Weaknesses and Threats (WT) strategies which include Weakness (Weakness) and Threat (Threats) which take advantage of the comment feature found on the official site aptisi.or.id. The Strength and Threats (ST) strategy includes strength and threat, which is done by ensuring the authenticity of the news on the official site aptisi.or.id. 


\section{Results and Analysis}

The results of the research are presented in the form of a prototype of the APTISI official site view board which is an important part of this website. Several views of the APTISI website pages which consist of the main page, dashboard, website statistics page, and running use case diagrams. This research was developed using the CMS (Content Management System) WordPress. One of the advantages of a WordPress CMS is that you don't need to develop a website from scratch.

\subsection{Website Main Page}

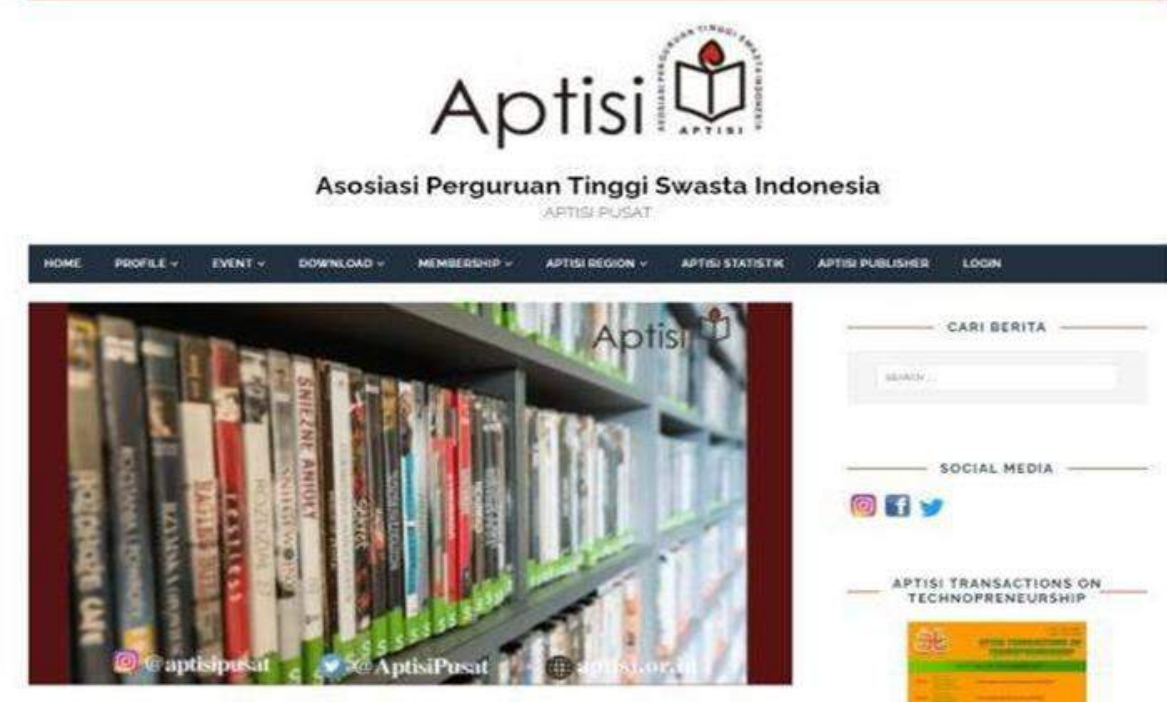

Figure 1. Main Page APTISI Website

The main page is the first thing seen on the aptisi.or.id website. On this page there is a row of menus which are an important part of this website. The most important part of a website is the main page, which contains all the information of a website [32]. One of them is the Login menu. The login menu is used so that admins can access the dashboard page of this website. The main page also has a collection of posts that have been posted by the admin. So, when you visit this website, the first thing you see is news posts.

In the mobile news website consists of many visual elements, one of which is Image. Images are an important element to attract the attention of readers on a website, especially when choosing news [13]. With the image, besides being a visual attraction, it is also an informative big picture of the content of the news or article as a whole.

\subsection{Dashboard Page}

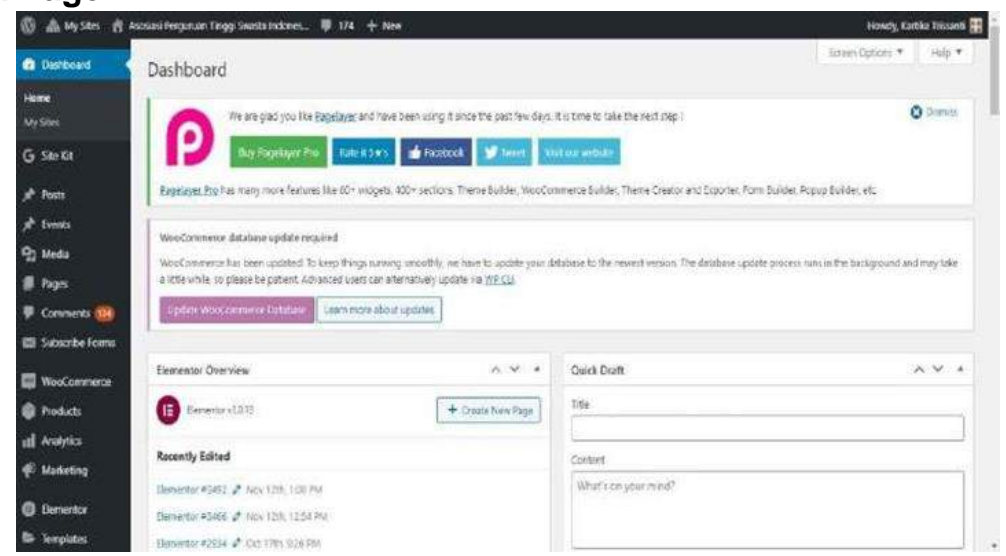


Figure 2. Dashboard Page APTISI Website

The dashboard page is the most important element of this website. Because from this page the admin can manage the website. The menu on this dashboard is connected to every menu element found on the aptisi.or.id website. So, only registered admins can access the dashboard by logging in first using email and password on the login menu on the main page. A dashboard is a set of menus that display quick and clear functions, which use performance indicators to make it easier [33].

\subsection{List Comments Menu}

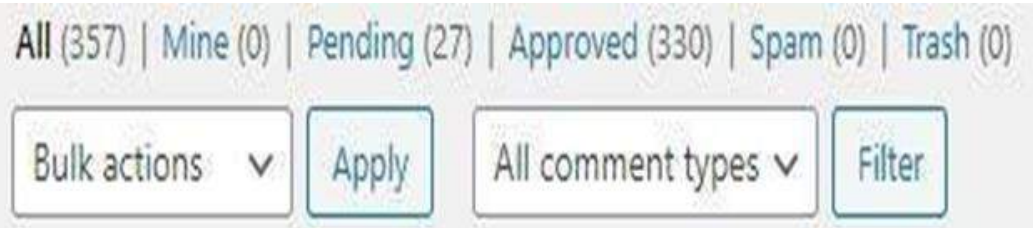

Figure 3. List Comments Menu APTISI Website

This image displays the comment list menu on the aptisi.or.id website dashboard page. This section still has shortcomings because the comments given by readers or website post visitors still have to be approved one by one by the admin. So this is considered ineffective. However, the positive thing about this is that it can avoid comment spam or comments that have negative elements. The admin can also decide that the comment will be approved, deleted or published.

\subsection{Appearance Menu}

The menu appearance page is the page used by the admin or user to make adjustments to the layout of each menu on the aptisi.or.id website page. The layout settings may affect the function and usability of the displayed menus. Because this affects the quality of the pages of this website. So that it can attract more interest from visitors to the aptisi.or.id website.

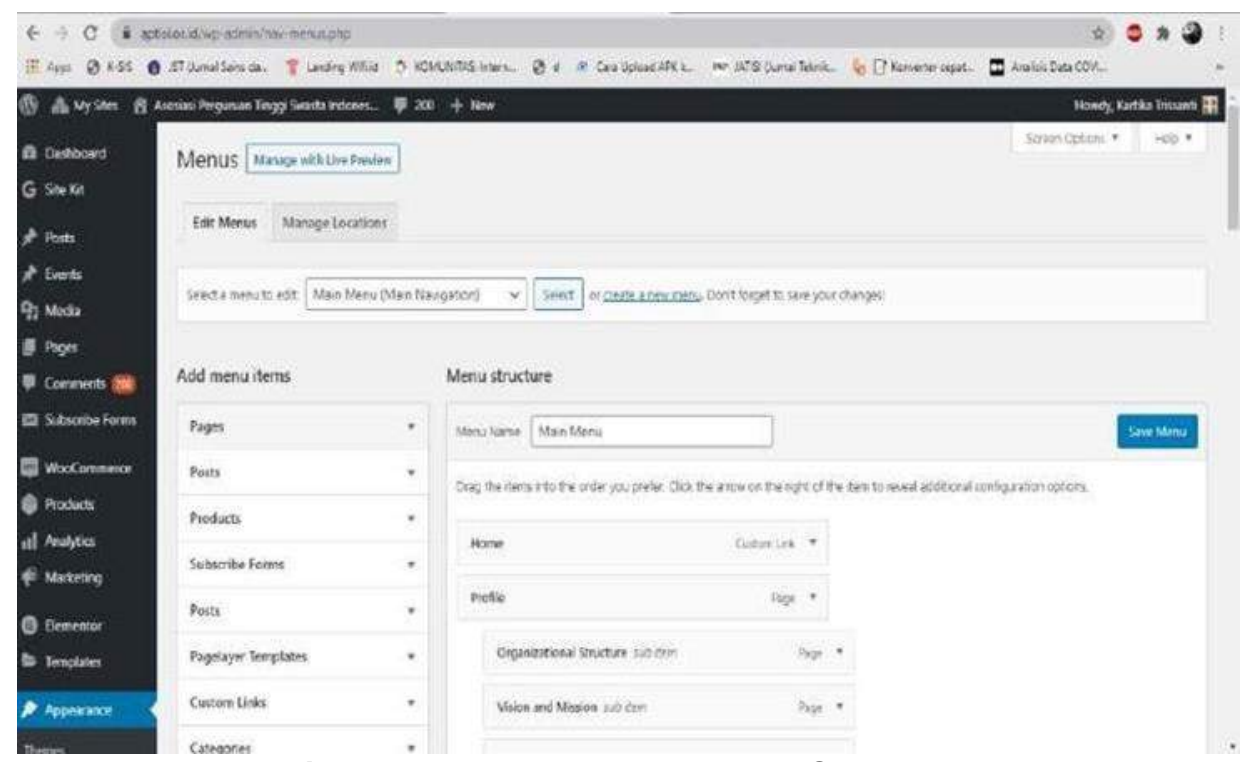

Figure 4. Appearance Menu APTISI Website 


\subsection{Article Posts Menu}

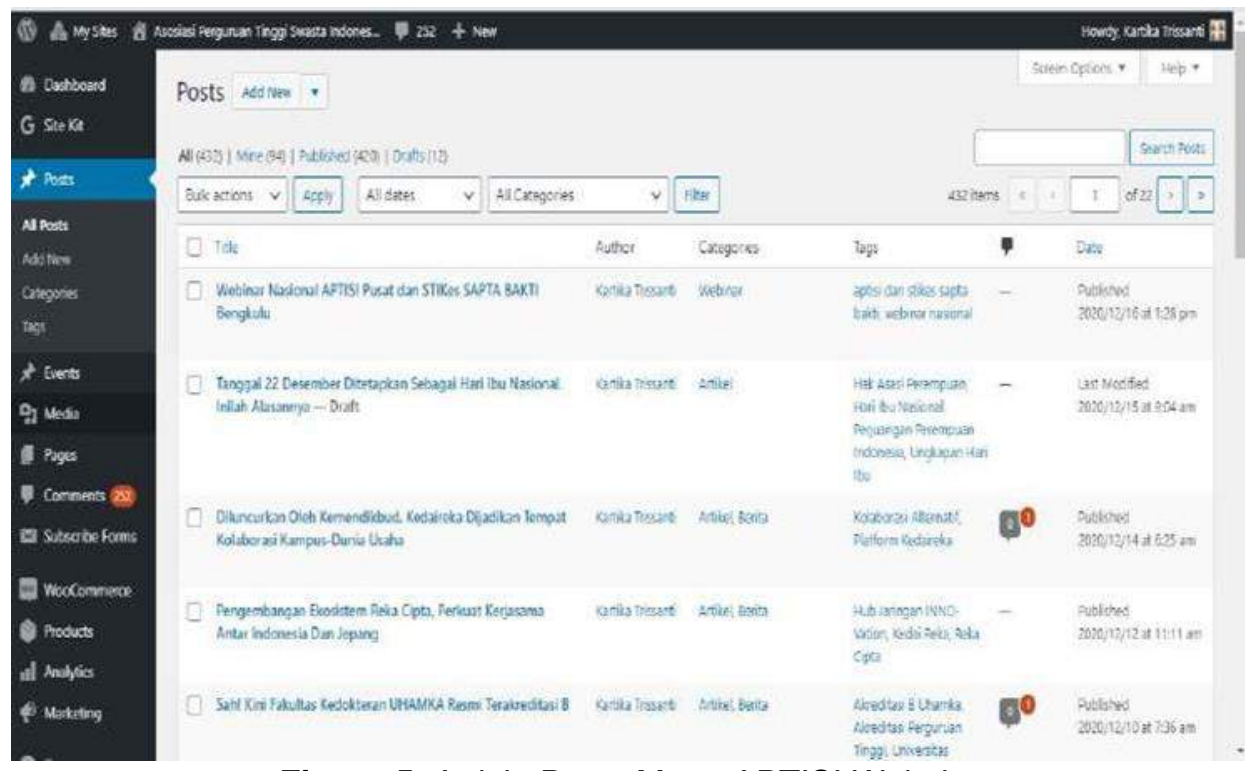

Figure 5. Article Posts Menu APTISI Website

The posting menu is on the website dashboard. This menu can be accessed by selecting the Post-All Post / Add New Menu to create a new post. In this menu, you can see posts that have been published, saved in drafts or deleted. Here you can also see the number of elaborate posts that have been published, saved on draft or deleted.

\subsection{APTISI Statistic Page}

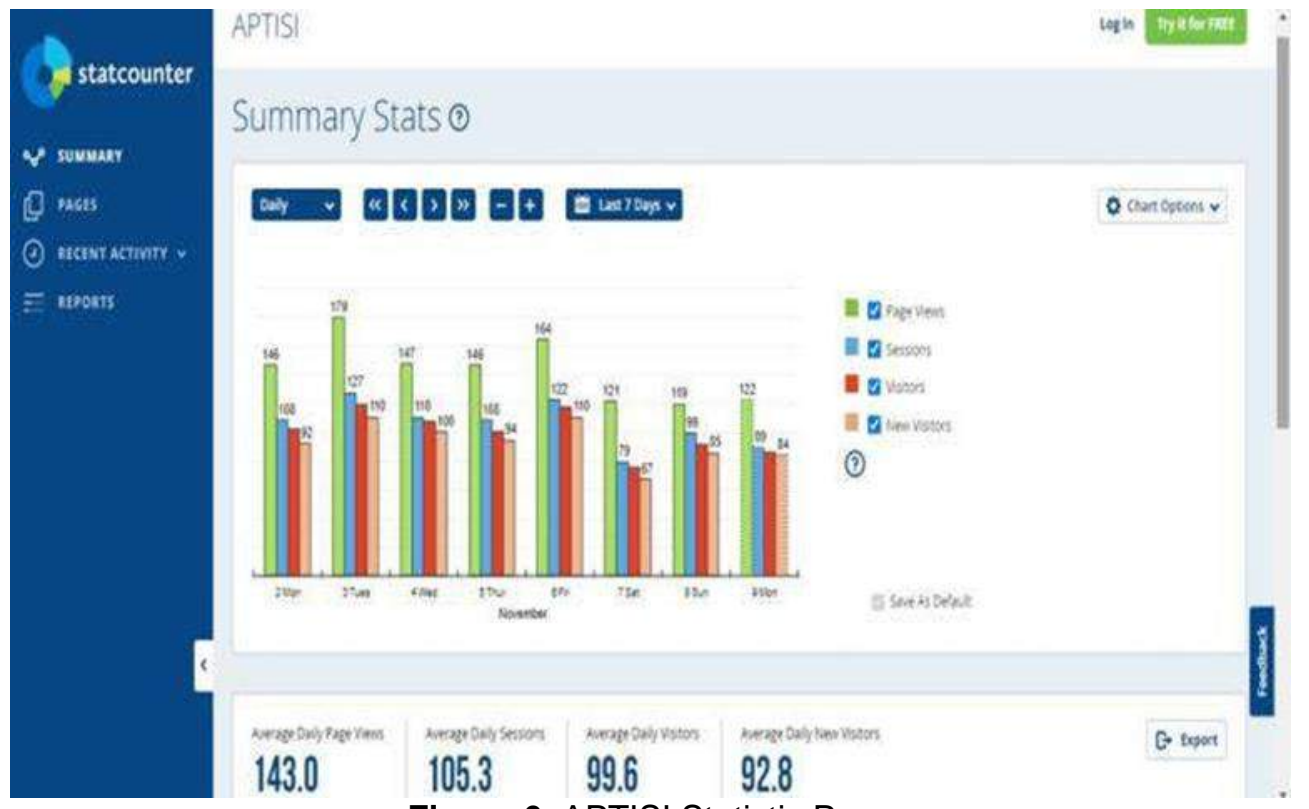

Figure 6. APTISI Statistic Page

This is a summary statistic on the APTISI website. This page is located on the APTISI Statistics menu. This statistic shows how many daily visits to website pages (in green), activities carried out on the website (blue), visitors (red), and new visitors (orange). Thus, it becomes more 
measurable and can become a reference for continuing to develop the APTISI website or making more updated news.

Therefore, this website uses a monitoring tool to perform automatic calculations on the website. The monitoring tool is very useful as a benchmark for admins to measure the level of activity of the aptisi.or.id website. Thus, a monitoring tool is needed to measure the visitor count. Statcounter is one of the free visitor counter providers (statcounter.com) with one of the advantages of being able to count visitors based on unique visits [34].

\subsection{Most Viewes Article Page}

\section{Most Viewed Article}

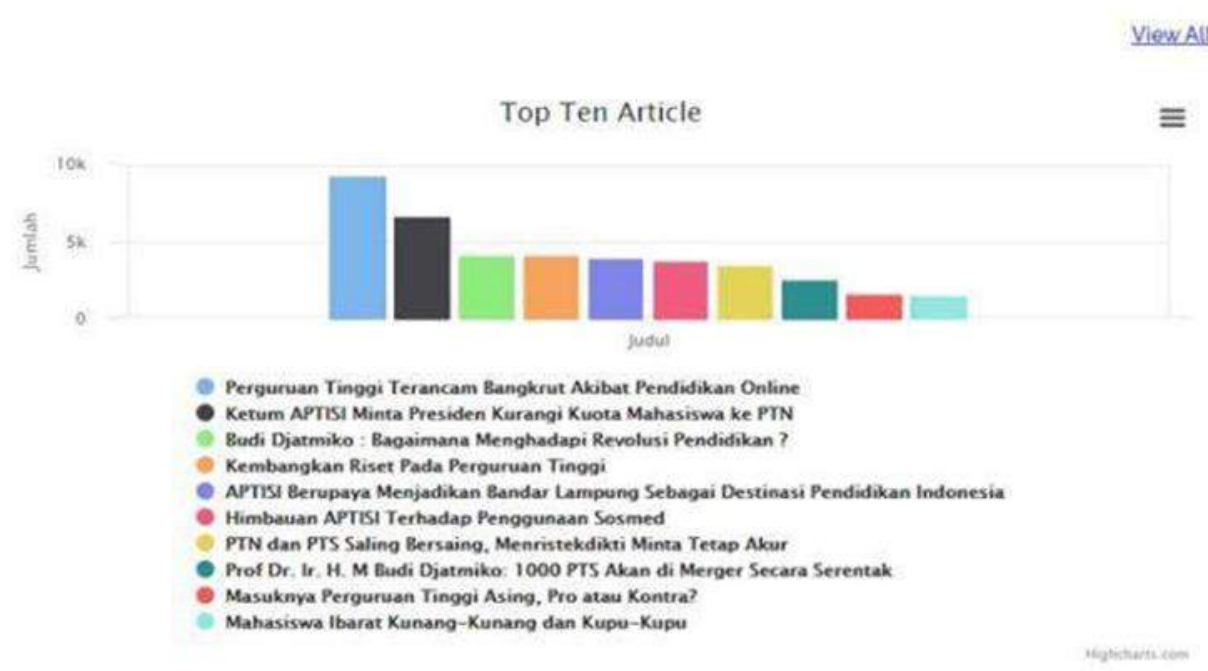

Figure 7. Most Viewed Article Page

Figure 6 shows statistical data of the 10 most popular articles in the form of bar charts. This page can be visited by readers by looking at APTISI's About Official Site on the main page. There is an inscription on the number of posts published, then click on the text, this page will appear.

In the picture explained that the posts that get a lot of visits are those on the blue bar chart. While the other nine posts have the number of visits below the number of the first post. The results of the study are presented in the form of several views of the APTISI website pages consisting of the main page, statistics on the number of posts, number of page visits, social media pages and post categories. In this explanation, focused on the part of the page that contains the article and also the post visit statistics.

\section{Conclusion}

This study collects data from criticism and suggestions from several users and the team who are managers of the website. In developing the aptisi.or.id website, it is run by one admin who is active in making posts and running the website. By using a monitoring tool called statcounter which utilizes probability and statistical calculations to increase the number of unique visits and daily visitors based on pre-existing data. Based on the graph in the summary of website statistics, both visitors and admins can find out how many visitors have increased on the website. In addition, the use of this statcounter is useful as a reference standard for website admins to update development on a better website in the future.

\section{Suggestions}

In accordance with the existing conclusions, the author of several inputs to get constructive ideas or criticisms to correct deficiencies in this study, namely in developing a better website and a display that has a more attractive design in the future and contains lots of information so that the website used is more informative and easier. for the community. 


\section{Acknowledgment}

By saying thanks to God Almighty, because of his blessings and mercy so that the author was able to finish writing a research journal. And do not forget to thank Raharja University, especially REC (Raharja Enrichment Center) which has provided the opportunity for authors to conduct research. Thank you also to the authors 1 (one) and 2 (two) as well as friends in arms who have provided support and direction to the author so that the author can complete this research journal with maximum results. The author also realizes that there are many mistakes, both in writing and in speech as well as other limitations that the author has. Hopefully this journal writing can provide inspiration for researchers who will also carry out similar research.

\section{REFERENCES}

[1] Marijan and S. Nurajizah, "Perancangan Sistem Informasi Akademik Berbasis Web Pada SD Islam Luqmanul Hakim Bekasi," JURTEKSI (Jurnal Teknol. dan Sist. Informasi), vol. $\mathrm{VI}$, no. 1, pp. 71-78, 2019.

[2] Q. Aini, I. Dhaniarti, and A. Khoirunisa, "Effects of iLearning Media on Student Learning Motivation," Aptisi Trans. Manag., vol. 3, no. 1, pp. 1-12, 2019.

[3] P. S. Hasugian, "Perancangan Website Sebagai Media Promosi Dan Informasi," J. Inform. Pelita Nusant., vol. 3, no. 1, pp. 82-86, 2018.

[4] E. Febriyanto, Q. Aini, and A. Afitri, "Multimedia-Based Visual Analysis As a Promotional Media At Raharja Internet Cafe (RIC)," Aptisi Trans. Manag., vol. 4, no. 1, pp. 76-82, 2019, doi: 10.33050/atm.v4i1.1116.

[5] I. Handayani, A. B. Warsito, and S. A. Pangestu, "Pemanfaatan Website Raharja . Ac . Id Sebagai Media Informasi Dan Upload Artikel Untuk Ns-Ccit Menggunakan Framework Yii," vol. 10, no. 1, pp. 127-138, 2016.

[6] S. Sunanto, I. Maryani, and G. W. Pamukti, "Sistem Informasi Kursus Setir Mobil

Berbasis Web Pada LPK Citra Indotech Jaya Purwokerto," EVOLUSI J. Sains dan Manaj., vol. 8, no. 1, pp. 115-127, 2020, doi: 10.31294/evolusi.v8i1.8369.

[7] E. Azadbakht, J. Blair, and L. Jones, "Everyone's invited: A website usability study involving multiple library stakeholders," Inf. Technol. Libr., vol. 36, no. 4, pp. 34-45, 2017, doi: 10.6017/ital.v36i4.9959.

[8] H. Kurniawan and E. P. Widiyanto, "Analisis Peningkatan Performa Akses Website dengan Web Server Stress Tool," Jatisi, vol. 2, no. 2, pp. 108-119, 2016.

[9] G. Wibisono and W. E. Susanto, "Perancangan Website Sebagai Media Informasi dan Promosi Batik Khas Kabupaten Kulonprogo," J. Evolusi, vol. 6, no. 2, pp. 46-55, 2015.

[10] M. Faizal et al., "Penggunaan Website Portal Berita Sebagai Media Informasi Untuk Mahasiswa," J. Bhs. Rupa, vol. 2, no. 1, pp. 34-42, 2018, doi: 10.31598/bahasarupa.v2i1.217.

[11] U. Rahardja, N. Lutfiani, and A. Yolandari, "Penerapan Viewboard Informatif Pada

Asosiasi Perguruan Tinggi Swasta Indonesia Dalam Era Industri 4.0," Technomedia J., vol. 3, no. 2, pp. 224-234, 2019, doi: 10.33050/tmj.v3i2.738.

[12] U. Rahardja, N. Lutfiani, and R. Rahmawati, "Persepsi Mahasiswa Terhadap Berita Pada Website APTISI," Sisfotenika, vol. 8, no. 2, p. 117, 2018, doi: 10.30700/jst.v8i2.400.

[13] Q. Aini, N. Lutfiani, N. P. L. Santoso, S. Sulistiawati, and E. Astriyani, "Blockchain For Education Purpose: Essential Topology," Aptisi Trans. Manag., vol. 5, no. 2, pp. 112120, 2021.

[14] P. Edastama, N. Lutfiani, Q. Aini, S. Purnama, and I. Y. Annisa, "Blockchain Encryption on Student Academic Transcripts using a Smart Contract," J. Educ. Sci. Technol., 2021.

[15] U. Rahardja, N. Lutfiani, A. S. Rafika, and E. P. Harahap, "Determinants of Lecturer Performance to Enhance Accreditation in Higher Education," in 2020 8th International Conference on Cyber and IT Service Management (CITSM), 2020, pp. 1-7.

[16] F. P. Oganda, N. Lutfiani, Q. Aini, U. Rahardja, and A. Faturahman, "Blockchain Education Smart Courses of Massive Online Open Course Using Business Model 
Canvas," in 2020 2nd International Conference on Cybernetics and Intelligent System (ICORIS), 2020, pp. 1-6.

[17] M. Saraswati, N. Lutfiani, and T. Ramadhan, "Kolaborasi Integrasi Inkubator Bersama

Perguruan Tinggi Sebagai Bentuk Pengabdian Terhadap Masyarakat Dalam

Perkembangan Iptek," ADI Pengabdi. Kpd. Masy., vol. 1, no. 2, pp. 23-31, 2021.

[18] E. S. Aisyah, E. P. Harahap, and N. Salsabila, "The Effect Requirements Selling In The Marketplace For Security Against Buyer Trust," Aptisi Trans. Manag., vol. 4, no. 1, pp. 67-75, 2019.

[19] T. K. Ahsyar and D. Afani, "Evaluasi Usability Website Berita Online Menggunakan Metode Heuristic Evaluation," J. IIm. Rekayasa dan Manaj. Sist. Inf., vol. 5, no. 1, pp. 3441, 2019.

[20] M. Zarlis, E. P. Harahap, and L. N. Husna, "Test Appraisal System Application Based on YII Framework as Media Input Student Value Final Project and Thesis Session at Higher Education," Aptisi Trans. Technopreneursh., vol. 1, no. 1, pp. 73-81, Mar. 2019, doi: 10.34306/att.v1i1.31.

[21] S. Sudaryono, U. Rahardja, and D. Apriani, "The CICES Journal Governance Performance Improvement on Quality of Current Issues (Case Study of STMIK RAHARJA)," Aptisi Trans. Manag., vol. 3, no. 1, pp. 57-64, 2019.

[22] Z. Fauziah, H. Latifah, U. Rahardja, N. Lutfiani, and A. Mardiansyah, "Designing Student Attendance Information Systems Web-Based," Aptisi Trans. Technopreneursh., vol. 3, no. 1, pp. 23-31, 2021.

[23] M. Muslihudin and M. A. Imamudin, "Pengembangan Aplikasi Penerimaan Siswa Baru Berbasis Web Mobile SMA Negeri 1 Ulu Belu," JATISI (Jurnal Tek. Inform. dan Sist. Informasi), vol. 5, no. 2, pp. 194-206, 2019, doi: 10.35957/jatisi.v5i2.146.

[24] A. W. Soejono, A. Setyanto, and A. F. Sofyan, "Evaluasi Usability Website UNRIYO Menggunakan System Usability Scale (Studi Kasus: Website UNRIYO)," J. Teknol. Inf., vol. XIII, no. 1, pp. 29-37, 2018.

[25] Q. Aini, N. Lutfiani, and M. S. Zahran, "Analisis Gamifikasi iLearning Berbasis Teknologi Blockchain," ADI Bisnis Digit. Interdisiplin J., vol. 2, no. 1, pp. 79-85, 2021.

[26] A. Alwiyah, C. Greisy, and A. Afitri, "Implementation Of Information Systems On Ecommerce Websites As Media To Deliver Information," Aptisi Trans. Technopreneursh., vol. 1, no. 2, pp. 127-133, 2019.

[27] G. Gaus, Summary of Contents. 2016.

[28] A. Sidik, H. A. Ahmad, and A. B. Sriwarno, "Studi Faktor Usability Pada Desain Layout," Semin. Nas. Teknol. Inf. dan Multimed. 2017, vol. 5, no. 1, pp. 31-36, 2017.

[29] Refli Noviardi, "Sistem Pakar Berbasis Web Menggunakan Metode Forward Chaining Dalam Menganalisa Kerusakan Mesin Fotokopi Dan Penannggulangannya (Study Kasus Di Q-EI Copier Service Center and Distributor)," JURTEKSI (Jurnal Teknol. dan Sist. Informasi), vol. 53, no. 9, pp. 163-172, 2020, doi: https://doi.org/10.33330/jurteksi.v6i2.548.

[30] M. P. Ni'matuzahroh, S.Psi, M.Si, Susanti Prasetyaningrum, OBSERVASI: TEORI DAN APLIKASI DALAM PSIKOLOGI. Universitas Muhammadiyah Malang, 2018.

[31] Sudaryono, U. Rahardja, and E. P. Harahap, "Implementation of Information Planning and Strategies Industrial Technology 4.0 to Improve Business Intelligence Performance on Official Site APTISI," J. Phys. Conf. Ser., vol. 1179, no. 1, pp. 0-7, 2019, doi: 10.1088/1742-6596/1179/1/012111.

[32] M. A. Frandini, P. Studi, S. Informasi, J. S. Informasi, F. I. Komputer, and U. Brawijaya, "SITUS WEB PERGURUAN TINGGI DI INDONESIA Disusun oleh :," 2017.

[33] J. Lazar, V. Williams, J. Gunderson, and T. Foltz, "Investigating the Potential of a Dashboard for Monitoring U.S. Federal Website Accessibility," Proc. 50th Hawaii Int. Conf. Syst. Sci., pp. 2428-2437, 2017, doi: 10.24251/hicss.2017.294.

[34] I. Handayani, M. Sani, and D. R. Sari, "Penerapan Statcounter sebagai Alat Monitoring Aktivitas Website Hibah Perguruan Tinggi Raharja," Creat. Inf. Technol. J., vol. 4, no. 1, p. 18, 2016, doi: 10.24076/citec.2016v4i1.92. 